JEL classification: G14, G15, G30

Keywords: initial public offering, seasoned equity offering, underpricing, signaling, information asymmetry, emerging market

\title{
Signaling by Underpricing the Initial Public Offerings of Primary Listings in an Emerging Market*
}

\author{
Aleš ČORNANIČ \\ Jiří NOVÁK (jiri.novak@fsv.cuni.cz),corresponding author \\ both authors: Institute of Economic Studies at the Faculty of Social Sciences, \\ Charles University in Prague
}

\begin{abstract}
We show that issuers use initial public offering (IPO) underpricing to signal their quality when the a priori information asymmetry is significant. Contrary to weak evidence in the signaling hypothesis from established markets, we find that in a less transparent emerging market firms strategically underprice their IPOs to issue seasoned equity at better terms. Private firms that underpriced their primary listing in Poland between 2005 and 2009 were more likely to make follow-up seasoned equity offerings (SEOs) and their SEOs were larger and occurred sooner after the IPOs. This suggests that the economic incentives to follow the signaling strategy are stronger in opaque environments where high-quality issuers may underprice IPOs to overcome information asymmetry.
\end{abstract}

\section{Introduction}

The underpricing of initial public offerings (IPOs) is one of the most puzzling empirical regularities of the IPO market (Ljungqvist, 2004). The tendency of the firstday closing price to be higher on average than the IPO issue price seems to imply that issuers may offer IPOs at a higher price and so they "leave money on the table". Since IPOs are salient events that attract much attention and the first-day return has a very short time span, it is unlikely that these findings are driven by incomplete data coverage or by inadequate risk adjustments. IPO underpricing is a pervasive phenomenon that has been documented in a number of countries (Engelen and van Essen, 2010; Boulton et al., 2010) and that persists over time (Ljungqvist, 2004). Butler et al. (2014) use a dataset spanning from 1981 to 2007 and they identify fifteen determinants that are robust in predicting IPO underpricing. Underpricing seems to be related to a number of other empirical patterns, such as IPO clustering and longterm IPO underperformance. Hence, analysis of underpricing is likely to be important for unraveling the nature of the economic interactions around IPOs.

In this paper we make use of the less established institutional framework of an emerging country to investigate whether issuers use IPO underpricing as a tool

\footnotetext{
* The authors would like to thank Wolfgang Aussenegg, Michal Bauer, Jan Hanousek, Iftekhar Hasan, Roman Horváth, Karel Janda, Tomasz Jewartowski, Karol Marek Klimczak, Piotr Korczak, Feng Li, Joanna Lizińska, James Lothian, Esmeralda Lyn, Jan Michalak, Ondřej Schneider, Aljoša Valentinčič, Maya Waisman and Laurent Weill for their helpful comments and suggestions. We would also like to thank Monika Urbanowicz and Anna Wiśniewska of the Warsaw Stock Exchange and Piotr Koszewski of the Polish Ministry of Treasury for their assistance in verifying the data, and Sezin Koehler for proofreading the article. We gratefully acknowledge financial support from the Czech Science Foundation, grant no. P403/12/2166.
} 
to signal their quality in a setting when the information asymmetry between the issuer and the investors is likely to be high. Prior research suggests that the institutional environment in Poland is weaker than in established markets (Patel, Balic and Bwakira, 2002; Kaufmann et al., 2009). At the same time, the Warsaw Stock Exchange (WSE) has attracted a large number of IPOs in recent years, which makes the market particularly fit for our investigation. We argue that the weaker institutional environment makes it easier for weaker players to enter the market. This in turn makes it more important for the strong players to make an effort to differentiate themselves from the weaker players in order to receive better terms from investors. We thus propose that in such a setting the strong players are more likely to use IPO underpricing as a signaling mechanism. In Central and Eastern European (CEE) emerging countries we expect and find that the level of IPO underpricing is positively associated with the follow-up SEO activity, which implies that the strong players issue only a fraction of their equity in IPOs and delay issuance of the remainder until after their quality is disclosed in their respective IPOs. IPO underpricing is thus a costly way in which the strong players overcome the limitations of the institutional setting.

Most of the models aimed at explaining IPO underpricing consider some kind of information asymmetry between the issuer, the underwriter(s) and the investors (Ljungqvist, 2004). However, the nature of information asymmetry is not well understood. There is little consensus on which party has the information advantage and whether IPO underpricing is a form of compensation for the resulting uncertainty or a tool to overcome it. The issuer can conceivably have superior knowledge of the firm's intrinsic value, whereas investors can have a better understanding of the aggregate demand for the company's equity, and sophisticated investors may have an information advantage over naive investors, or experienced underwriters could comprise the best-informed party. IPO underpricing can reflect a costly signal that the betterinformed issuers send to investors, compensation for naive investors for an adverse selection, or the cost of soliciting information due to investors' private demands during the book-building process.

Welch (1989) designs a signaling model in which better-informed issuers use IPO underpricing to signal their quality to investors. If there is some chance that the quality of the issuer is revealed by the nature between the IPO and the SEO, the strong players underprice their IPOs to deter the weak players from imitating them. The strong players recover the cost of the underpricing signal by subsequently issuing seasoned equity at more favorable terms. The model predicts firms that underprice their IPOs are more likely to make an SEO, to make a larger SEO, and to make an SEO sooner after the IPO. Despite the intuitive appeal of the underlying argument, early empirical evidence provided little support. Jegadeesh, Weinstein and Welch (1993) and Michaely and Shaw (1994) find SEO activity is related more to aftermarket returns than to IPO underpricing. This implies that investors are the betterinformed party and so IPO underpricing is unlikely to be a tool of communication from issuers to investors.

Nevertheless, Francis et al. (2010) recently revisited the signaling hypothesis using a sample of foreign firms that make IPOs in the United States and they found evidence consistent with the signaling hypothesis for firms from segmented markets, but not for firms from integrated markets. The authors argue that firms from seg- 
mented markets face greater information asymmetry and so they are willing to incur the cost of sending a signal about their quality. This implies that the attractiveness of the signaling strategy may depend on the a priori information asymmetry on the market. The issuers have incentives to use IPO underpricing as a signaling device only if the information asymmetry is sufficiently large and the benefit of its reduction outweighs the cost of the signal.

"We conjecture that the problem underlying the very weak support empirically is the inability of researchers to identify firms that actually value underpricing as a signaling device and hence are willing to apply this time-intensive strategy."

(Francis et al., 2010, p. 82)

There is a controversy over how a country's institutional setting impacts issuers' incentives to underprice their IPOs. Engelen and van Essen (2010) find larger IPO underpricing in countries with a poor legal system. They argue that the issuers "leave money on the table" to compensate investors for the higher ex ante uncertainty about the given firm's value or for the higher ex ante risk of possible misappropriation of the generated value (Engelen and van Essen, 2010, p. 1959). Conversely, Boulton et al. (2010) suggest that issuers underprice IPOs more in countries with a strong legal system in order to achieve a more dispersed ownership, which reduces the investors' incentives to monitor the management. In strong legal systems, the incentive of weak players to use IPO underpricing to maintain control of their firms should be at least as strong as the incentive of strong players. Conversely, in legal systems that do not sufficiently empower outside investors, weak issuers do not benefit from underpricing their IPOs to avoid concentrated ownership and so strong players may use IPO underpricing to signal their quality. We analyze IPOs in a weaker institutional setting to see if this environment incentivizes strong issuers to underprice IPOs selectively in order to differentiate themselves from weak players.

We examine whether issuers use IPO underpricing to signal the quality of their primary listings in an emerging market with a less developed legal system. Our sample consists of 153 Polish IPOs made between 2005 and 2009, and 34 follow-up SEOs. The Polish equity market is suitable for our analysis because it is both quite large and active in terms of equity issues and at the same time it features a fairly low transparency and disclosure score (Patel, Balic and Bwakira, 2002) as well as a low "rule of law" index (Kaufmann et al., 2009, p. 94). If the economic incentives to use the signaling strategy depend on the a priori information asymmetry, we should be able to observe it on the market with these characteristics.

If strong issuers use IPO underpricing as a signaling tool, we expect them to make a follow-up SEO at which they issue equity at better terms because their high quality is already known to the investors. We predict that in order to benefit from their revealed quality, the issuers who underprice their IPO more are more likely to make an SEO in the following three years (Hypothesis 1), their SEOs are larger relative to their IPOs (Hypothesis 2) and they make SEOs sooner after their IPOs (Hypothesis 3). We also predict that the stock market will react less negatively to the SEO announcements of firms that underpriced their IPOs more, because the market understands that these firms are strong players which are likely to return to the market with a follow-up SEO (Hypothesis 4). 
Consistent with our expectations, we document significant IPO underpricing of $14.0 \%$ (significant at the $1 \%$ level) over the examined period. More importantly, we find that issuers which underprice their IPOs more are more likely to make an SEO, to make a larger SEO and to make an SEO sooner after the IPO, which are all consistent with the signaling hypothesis. At the same time, we do not find any support for the market feedback hypothesis, which suggests that a firm decides on an SEO based on how well the market receives its IPO. Contrary to the weak evidence on the signaling hypothesis presented in the early studies published in the past, our own findings based on data from an emerging market suggest that issuers do use IPO underpricing as a signaling device provided that the information asymmetry in the given market is sufficiently large to render the signaling strategy attractive.

We make several contributions to the existing literature. First, we document that in an emerging equity market issuers have a significant information advantage over investors. Given the diverse views of the information asymmetry theories in which market actors have the information advantage, this finding is important. Second, we provide evidence consistent with the signaling theory in primary listings that may be driven by different economic incentives than cross listings (Francis et al., 2010). Third, we document signaling in a setting where the information asymmetry between the issuer and the investors is larger compared to that of established markets. This suggests that the role of IPO underpricing varies in different settings as it reflects context-specific economic trade-offs faced by issuers.

The rest of the paper is organized as follows: In Section 2 we provide an overview of the signaling model, review the existing empirical evidence on IPO underpricing and formulate our hypotheses. Section 3 outlines the institutional features of the Polish equity market and compares it to the other European stock exchanges. In Section 4 we present our data sample. The methodology is described in Section 5. We report the empirical results in Section 6 and conclude the paper in Section 7.

\section{Literature and Hypotheses}

\subsection{Theory and Hypotheses}

Welch (1989) formulates a two-period signaling model in which firms are rational participants with superior information in a perfectly competitive capital market. The author distinguishes between two types of risk-neutral issuers (high- and low-quality firms) whose utilities depend on the sum of the issue proceeds from their IPOs and SEOs. Investors know the portion of high-quality firms, but they cannot directly observe the true quality of individual firms. The low-quality firms must incur imitation costs to look like high-quality firms. There is some chance that the nature will reveal a firm's true quality between the IPO and SEO, in which case low-quality firms do not benefit from their effort to imitate the high-quality firms. The lowquality firms thus trade off the potentially better terms at which they make their SEOs (provided that their true type is not revealed by the nature) against the cost of imitation.

The high-quality firms have an incentive to credibly distinguish themselves from the low-quality firms. When the inherent imitation costs alone are not sufficient to deter low-quality firms from mimicking the high-quality firms, the high-quality 
firms may strategically underprice their IPOs to increase the imitation cost, which renders imitation unattractive for the low-quality firms. The low-quality firms thus reveal their type to the investors who are then ready to offer better terms for the highquality firms at the subsequent SEOs. The high-quality firms trade off the benefit of distinguishing themselves from the low-quality firms against the money they leave on the table when they underprice their IPOs.

The signaling benefit for the high-quality firms materializes only if they make a subsequent SEO at more favorable terms. Hence, firms that underprice IPOs to signal their type are expected to be more likely to make a follow-up SEO.

Hypothesis 1: Firms with more underpriced IPOs are more likely to make an SEO than firms with less underpriced IPOs.

Furthermore, the magnitude of the benefit depends on the total value of the proceeds collected by the firm in the IPO and the SEO. A high-quality firm that signals its quality understands that it will make the IPO at a lower price and the SEO at a higher price than it would without the signal. To maximize the benefit, the highquality firms are expected to raise a higher fraction of their equity capital at the SEO.

Hypothesis 2: Firms with greater IPO underpricing are likely to issue larger amounts at the SEO than firms with less IPO underpricing.

A firm that uses IPO underpricing to signal its type anticipates that it will return to the market to make a follow-up SEO. Assuming that it is costly to postpone the investment for which the new equity capital is raised, we expect the firms that underprice their IPOs more to make their SEOs sooner after the IPOs.

Hypothesis 3: Firms with more underpriced IPOs are likely to make an SEO more promptly than firms with less underpriced IPOs.

It has been well established in prior research that stock markets tend to react negatively to SEO announcements (e.g. Choe, Masulis and Nanda, 1993; Gao and Ritter, 2010). There are several possible reasons for a negative stock market reaction. From the pecking order perspective, the management may have a preference for specific sources of capital and they access the equity markets only if retained earnings and available debt financing are insufficient to cover the existing investment needs. Therefore, an SEO announcement sends a negative signal about the company's (in)ability to obtain capital from the preferred sources. Alternatively, from the market timing perspective, the stock market may react negatively to SEO announcements if better-informed managers issue equity only if they observe that it is currently overvalued. The negative stock market reaction reflects the downward revision of the investors' intrinsic value estimates based on the news revealed at the SEO announcement.

If the issuers use IPO underpricing strategically to reveal their quality, there must be a shared understanding between the issuer and the investors about the meaning of the signal. Investors thus expect the high-quality firms to return to the stock market soon after the IPO, so they are not surprised by an SEO announcement and they do not view it as bad news. The signaling model thus predicts the stock market's reaction to the first SEO announcement to be less negative for firms that use the IPO underpricing signal. 
Hypothesis 4: The market reacts less unfavorably to the announcements of SEOs by firms with more underpriced IPOs than by firms with less underpriced IPOs.

The hypotheses formulated above are also consistent with an alternative explanation suggested in the market-feedback (pooling) hypothesis (Jegadeesh, Weinstein and Welch, 1993; van Bommel and Vermaelen, 2003). Similar to the signaling hypothesis, the market-feedback hypothesis is based on the assumption of informat that the issuer has an information advantage (perhaps with respect to the quality of the firm), the market-feedback hypothesis assumes that the investors have an information advantage over the issuer (perhaps with respect to the demand for company stocks). The less informed issuers make an IPO and observe how well it is received by the market. If the stock price rises after the IPO, the issuer infers that investors collectively have a favorable view on the future prospects of the firm. Having observed the favorable market reaction following the IPO, the issuers update their own estimate of the company's value and decide to obtain additional equity through an SEO to increase the scale of the project. Thus both the signaling model and the market-feedback model view IPO mispricing as a manifestation of uncertainty resolution; nevertheless, they suggest the opposite direction of the information flow.

In order to distinguish between the two alternative explanations, we measure the excess market return in the first two months following the IPO (hereinafter referred to as "aftermarket returns") and we formulate complementary hypotheses (below). Similar to Jegadeesh, Weinstein and Welch (1993) we argue that the price discovery process that reveals the information possessed by the investors is not instantaneous. Hence, if we observe that the SEO characteristics are related to the aftermarket returns rather than to the IPO- date return (i.e. IPO underpricing) we conclude that the association is likely to be driven by market feedback. Conversely, if we observe that SEO characteristics are related to IPO underpricing but not to aftermarket returns, we conclude that the signaling by the issuer to the investor is the likely explanation.

Hypothesis 1A: The aftermarket return is a better predictor of SEO likelihood than the IPO-date return.

Hypothesis 2A: The aftermarket return is a better predictor of SEO size than the IPO-date return.

Hypothesis 3A: The aftermarket return is a better predictor of the time between the IPO and SEO than the IPO-date return.

Hypothesis 4A: The aftermarket return is a better predictor of the stock market's reaction to the SEO announcement than the IPO-date return.

\subsection{Empirical Evidence}

The existing empirical evidence on the signaling model is mixed. Jegadeesh, Weinstein and Welch (1993) test the model using U.S. data from 1980 to 1986. Consistent with the prediction of the model, they find a positive association between IPO underpricing, the probability of making an SEO and SEO size. Furthermore, Slovin et al. (1994) find that the stock price reaction to the first SEO announcement 
is less negative for firms that significantly underprice their IPOs, which is consistent with investors being less surprised by the follow-up SEO in these firms. However, Jegadeesh, Weinstein and Welch (1993) also find that the aftermarket returns play a more important role in predicting future SEOs than IPO underpricing, which implies that market feedback is the dominant determinant of SEO characteristics. The authors thus conclude that the documented evidence on the signaling hypothesis is weak.

Michaely and Shaw (1994) test the signaling hypothesis using U.S. data from 1984 to 1988 . Contrary to the model predictions, they find that firms with higher earnings and firms that pay higher dividends are less underpriced. They also find that more underpriced firms go to the reissue market less often and for lower amounts than less underpriced firms, which is not consistent with the signaling hypothesis. Spiess and Pettway (1997) measure the net effect of the higher price in the SEO and the cost of the signal, and they conclude that firms do not seem to recover the cost of an underpriced IPO in either higher issue proceeds or in greater wealth for a given firm's initial owners. Hence, the preponderance of early empirical evidence does not support the signaling model.

More recent empirical studies explore the relationship between IPO underpricing and the a priori information asymmetry between issuers and investors. Francis, Hasan and Li (2001) compare the IPO underpricing of foreign and domestic IPOs in the U.S. between 1990 and 1993 and they conclude that foreign IPOs, which ceteris paribus face greater information asymmetry, are significantly more underpriced. In a similar vein, Engelen and van Essen (2010) document larger IPO underpricing in countries with poor legal systems, where corporate transparency is likely to be lower. Francis et al. (2010) analyze foreign IPOs in U.S. markets between 1985 and 2000 and document SEO patterns consistent with the signaling hypothesis for firms from the segmented markets but not for firms from the integrated market. This suggests that for high-quality foreign firms that self-select to list in the U.S. (Hasan and Waisman, 2010) the a priori information asymmetry is an important determinant of signaling attractiveness. Following line of reasoning of Francis et al. (2010), we investigate whether the signaling hypothesis explains IPO underpricing in an emerging market where the a priori information asymmetry is likely to be high.

Several existing papers examine IPO underpricing and subsequent post-IPO performance in emerging markets. However, those papers do not aim to explicitly make use of the weaker institutional setting in emerging markets to test for the presence of signaling behavior in a setting where it is likely to be common. Loughran, Ritter and Rydqvist (1994) document a positive average initial return (i.e. IPO underpricing) for all of the 25 studied countries, which include the emerging markets of Chile, Hong Kong, South Korea, Malaysia, Mexico, Singapore, Taiwan and Thailand. Hearn (2012) studies the corporate governance effect on underpricing in 62 IPOs in Sub-Saharan Africa and concludes that a larger number of foreign (indigenous) executives is positively (negatively) associated with underpricing.

Chang et al. (2008) divide IPO underpricing into the initial returns in the primary and secondary markets; they document a significantly positive initial return of Chinese A-shares and they attribute this finding to the higher information risk of the secondary market. Song et al. (2014) document a significant first-day return 
of $66 \%$ for Chinese IPOs between 2006 and 2011. They argue that for their sample the initial return is primarily driven by overvaluation at the end of the first trading day rather than by strategic underpricing. Huang and Shu (2014) show that in Chinese IPOs, company age is on average negatively associated with post-IPO operating performance. While the authors do not further explore the information-based explanation of their finding, it is consistent with the more restrictive self-selection of a younger firm for which the information asymmetry between the issuer and the investors is likely to be larger.

Shu et al. (2009) show that Taiwanese IPOs that were approved unanimously by the market regulatory committee subsequently outperform the market, which implies that the vote can be used as a relevant signal on a given IPO's quality, which affects the information asymmetry. Low and Yong (2011) analyze 368 IPOs made between 2000 and 2007 in Malaysia, where the most common mechanism is the fixedprice method and investors have to make an upfront payment at the time of IPO application, which limits the issuer's knowledge of the aggregated demand for the issued stocks. They report the mean (median) initial underpricing of $30.8 \%$ (17.9\%). Even though they do not explicitly study the causes of the documented underpricing, they argue that issuers who lower the offer price attract higher demand from investors, which is consistent with the stronger players using underpricing to communicate their quality.

Neupane and Poshakwale (2012) find that information on the aggregate demand for an IPO on the Indian market increases the participation of retail investors and leads to higher offering prices. Deb and Marisetty (2010) document an increase in demand from retail investors and a decrease in IPO underpricing on the Indian market after the introduction of independent quality certification in 2007. These findings indicate that in emerging markets the a priori information asymmetry has a significant impact on IPO pricing. It is plausible to expect that when the marketwide mechanisms for reducing uncertainty are not available or ineffective, issuers will use alternative firm-specific mechanisms (e.g. signaling) to overcome the information asymmetry.

On the Central and Eastern European (CEE) markets, Lyn and Zychowicz (2003) document IPO underpricing of $15.1 \%$ in Hungary and $54.5 \%$ in Poland between 1991 and 1998. Jewartowski and Lizińska (2012) use a more recent sample of Polish IPOs, covering the period from 1998 to 2008 and they report underpricing of $14.0 \%$, which is broadly consistent with our findings. Aussenegg (2000) and Jelic and Briston (2003) document significant IPO underpricing in Poland also for the privatization IPOs through which the state sells its previously state-owned enterprises. This indicates that IPO underpricing is a pervasive phenomenon in CEE markets.

\section{Institutional Setting}

The Polish equity market is suitable for our analysis because it meets two important criteria. First, prior research indicates that significant information asymmetries are likely to prevail on the Polish market. Patel, Balic and Bwakira (2002) examine corporate transparency and disclosure quality in emerging countries. They conclude that Poland has the second lowest transparency and disclosure score (36 of 
98) out of the six largest emerging economies they consider (second only to Brazil). Kaufmann et al. (2009) report for Poland the fourth lowest level of the "rule of law" index out of the EU27 countries (followed only by Italy, Romania and Bulgaria). Korczak and Bohl (2005) document a significant increase in valuation of CEE companies that cross-list internationally and thereby subject themselves to a more stringent disclosure and regulatory environment. Furthermore, Wisniewski and Bohl (2005) show that corporate insiders in Poland earn substantially higher insider trading profits than they do on mature markets and that insider trades conveying the most valuable information tend to be reported with a delay; both of these aspects imply significant informational asymmetry between company insiders and outside investors. Mun and Brooks (2012) document fairly low press coverage of financial crisis topics in the Polish business press (the third lowest score out of 17 investigated countries), which indicates a limited role of the media in closing the information gap. Dobija and Klimczak (2010) report that market efficiency and the value relevance of earnings have not significantly improved over time despite the implementation of financial reporting reforms.

Second, the Polish equity market is sufficiently large and rather active, and it has a suitable composition, which allows us to collect a sufficiently large sample of IPOs and subsequent SEOs. The WSE is the largest stock market in the region in terms of aggregate market capitalization and it is one of the five most active European capital markets for IPOs in recent years (Table 1). Furthermore, despite of the presence of several large privatized firms on the WSE (which we exclude from our analysis), the market is now dominated by entrepreneurial firms rather than by highly regulated firms, which makes it suitable for analyzing economic interactions driven by private incentives rather than by political considerations. The prominent position of the WSE and its suitability for research purposes has been recognized in prior studies.

"Its market capitalization, trading volume, the number and variety of traded securities make the Polish market the leading stock exchange in the region, satisfying all necessary conditions for reasonable empirical research. [...] Additionally, the institutional characteristics of this market, such as presence of a large number of small firms as opposed to a large number of medium-size and large firms on developed markets provide an interesting backdrop for testing what has become an established model."

(Lischewski and Voronkova, 2012, p. 9)

Table 1 provides an overview of the issue activity among the main European markets between 2005 and 2009. The WSE listed the second largest number of companies (195), with only the London Stock Exchange listing more (284). Nevertheless, the size of the firms listed on the WSE is smaller than in the other exchanges, which implies that the WSE is only fifth in terms of the total offering value. The WSE was less affected by the crisis years 2008-2009, during which it was the second most active stock exchange in terms of both the number of listed firms and the total offering value due to the privatization of several large Polish companies such as ENEA and PGE, both of which were among the ten largest IPOs in the given year. 





Table 2 Warsaw Stock Exchange

\begin{tabular}{|c|c|c|c|c|c|c|c|c|}
\hline \multirow[t]{2}{*}{ Year } & \multirow[t]{2}{*}{ List } & \multirow[t]{2}{*}{ Delist } & \multicolumn{3}{|c|}{ Firms } & \multicolumn{3}{|c|}{ Market Capitalization } \\
\hline & & & Domestic & Foreign & Total & Domestic & Foreign & Total \\
\hline 1991 & 9 & 0 & 9 & 0 & 9 & 161 & -- & 161 \\
\hline 1992 & 7 & 0 & 16 & 0 & 16 & 351 & --- & 351 \\
\hline 1993 & 6 & 0 & 22 & 0 & 22 & 5845 & --- & 5845 \\
\hline 1994 & 22 & 0 & 44 & 0 & 44 & 7450 & --- & 7450 \\
\hline 1995 & 21 & 0 & 65 & 0 & 65 & 11271 & -- & 11271 \\
\hline 1996 & 18 & 0 & 83 & 0 & 83 & 24000 & --- & 24000 \\
\hline 1997 & 62 & 2 & 143 & 0 & 143 & 43766 & --- & 43766 \\
\hline 1998 & 57 & 2 & 198 & 0 & 198 & 72442 & --- & 72442 \\
\hline 1999 & 28 & 5 & 221 & 0 & 221 & 123411 & --- & 123411 \\
\hline 2000 & 13 & 9 & 225 & 0 & 225 & 130085 & --- & 130085 \\
\hline 2001 & 9 & 4 & 230 & 0 & 230 & 103370 & --- & 103370 \\
\hline 2002 & 6 & 19 & 217 & 0 & 217 & 110565 & --- & 110565 \\
\hline 2003 & 5 & 19 & 202 & 1 & 203 & 140001 & 27715 & 167716 \\
\hline 2004 & 36 & 9 & 225 & 5 & 230 & 214313 & 77385 & 291698 \\
\hline 2005 & 35 & 10 & 248 & 7 & 255 & 308418 & 116482 & 424900 \\
\hline 2006 & 38 & 9 & 272 & 12 & 284 & 437719 & 198190 & 635909 \\
\hline 2007 & 81 & 14 & 328 & 23 & 351 & 509887 & 570370 & 1080257 \\
\hline 2008 & 33 & 10 & 349 & 25 & 374 & 267359 & 197756 & 465115 \\
\hline 2009 & 13 & 8 & 354 & 25 & 379 & 421178 & 294643 & 715821 \\
\hline
\end{tabular}

Notes: List shows the number of newly listed firms on the main market in a given year. Delist is the number of firms delisted from the main market. Firms shows the number of firms listed. Market Capitalization shows the aggregate value of all traded shares in PLN million.

Source: WSE.

Table 2 provides further detail regarding the number of companies listed on the WSE. The number of listed companies grew from nine in 1991 to 379 in 2009. The IPOs are clustered in time with the first "hot market" in 1997 and 1998, when more than 50 companies per year were listed, and the second "hot market" in 2008, when 81 companies were listed. Conversely, in 2002 and 2003 the number of listed companies actually declined as more companies were delisted than were introduced to the market. The average company size has been increasing fairly steadily since 1994, with the exception of the years 2001 and 2008, when the financial crisis depressed market capitalization. The growth in average company size increased in the years after 2003, when the first foreign company was listed on the main market, because foreign companies are on average almost ten times the size of domestic companies. In 2009, only 25 foreign companies were listed compared to 354 domestic companies, but these foreign companies constituted nearly a third of total market capitalization. More than half of the foreign companies are dual-listed companies.

\section{Data Sample}

We obtain our sample of Polish IPOs using two main sources: (i) the WSE websites (www.gpw.pl and www.gpwinfostrefa.pl) and WSE yearbooks, and (ii) the Notoria 
database available at www.interia.pl. To maximize IPO coverage, we take the information about a given IPO's existence, its timing and size from the official WSE websites. The stock prices needed for the computation of returns are also gathered from the WSE websites and are adjusted for stock splits and reverse stock splits. We use the Notaria database to collect information that is not published at the required level of detail on the WSE websites - the IPO issue price of allotment certificates (see below for details), the SEO characteristics (SEO issue price, SEO date, SEO shares volume, etc.) and accounting information (sales, assets). Whenever possible, we compare several sources in order to verify data consistency and we check the information against the original sources (e.g. the prospectus, the statement of company status) when the information varies across sources.

The initial sample comprises 200 domestic and foreign IPOs made on the WSE main market between 2005 and 2009 (inclusive) as reported on the WSE website. ${ }^{1}$ We start our sample period in 2005 because before 2005 information about the size of IPOs is incomplete (it disregards the number of existing shares sold at the IPOs) and the data on the SEO issues are highly inconsistent. We end the sample period in 2009 because we require three years of post-IPO data to analyze the ensuing SEOs. We exclude 12 privatization IPOs (PIPOs) because the information asymmetry between the issuer (i.e. the state) and investors is likely to differ and because the state likely adopts a different kind of signaling strategy where the benefits are realized in subsequent IPOs of other state-owned enterprises rather than in the SEO of a given firm (e.g. Perotti, 1995). We further exclude 15 companies that had already been listed on a different market before making their IPO on the WSE (i.e. cross-listings). The level of information asymmetry for these firms is likely to be lower than for firms without any prior listing and it is not clear whether these firms would realize the signaling benefits through an SEO on the WSE rather than at another exchange. We exclude one firm that entered the main market by transferring from the less regulated market (NewConnect). Finally, we exclude 19 companies due to the lack of available data on their IPO volumes or accounting data prior to their IPOs. Our final sample consists of 153 IPOs. The IPO sample selection procedure is summarized in Panel A of Table 3.

We consider the first SEO that meets the conditions specified below and takes place within three years after the IPO. We consider only the SEOs that are likely to be motivated by the intention to raise additional equity capital. Hence, we disregard management offers and warrant subscriptions because they are likely to be driven by compensation rather than financing motives and thus they are unlikely to reflect the realization of signaling benefits. In a similar vein, we require the SEO issue price to be higher than the nominal price. SEOs that do not meet this condition are not likely to represent an arm's-length market transaction aimed at raising additional equity. If the SEO issue price is not available and the above condition cannot be assessed, we disregard the observation. As a robustness check, we relax the latter two conditions and the results are not materially affected (see the corresponding section for details). Overall, 34 out of the 153 IPO firms made a subsequent SEO, meeting the above-mentioned criteria. The SEO sample selection procedure is summarized in Panel B of Table 3.

\footnotetext{
${ }^{1}$ The regulatory environment of foreign firms is also affected by the country of their incorporation and so the lack of institutional transparency may not be as severe for them as for domestic firms. Excluding foreign firms does not affect the results or their significance.
} 
Table 3 Sample Construction

\begin{tabular}{lc}
\hline Panel A: Initial Public Offerings & \\
\hline Initial sample & 200 \\
\hline Cross-listings & -15 \\
\hline Privatization IPOs & -12 \\
\hline Transferred from NewConnect & -1 \\
\hline Missing information about the IPO volume & -16 \\
\hline Missing information about company's financials & -3 \\
\hline Final sample & 153 \\
\hline Panel B: Seasoned Equity Offerings & 153 \\
\hline Initial sample & -49 \\
\hline After IPO no other issue & -19 \\
\hline After IPO only management offers or warranty issue & -18 \\
\hline Missing information about SEO issue price & -4 \\
\hline SEO issue price equal to nominal SEO price & -29 \\
\hline More than 1095 days between IPO and SEO & 34 \\
\hline Final sample
\end{tabular}

Notes: The initial sample includes all IPOs made on the WSE main market over the period from 2005 to 2009 as reported by the WSE. Cross-listings refer to companies that were listed elsewhere before they made their IPO on the WSE. Privatization IPOs refer to state-owned enterprises for which IPOs were used as a privatization strategy as stated in the WSE Factbook. Transferred firms enter the main market after being listed on the alternative market (NewConnect). The construction of our SEO sample includes only SEOs made within three years after the IPO (Panel B). We exclude management offers and warranty issues. We also exclude SEOs with issue prices equal to nominal value of SEO share. Source: WSE.

\section{Methodology}

We measure the likelihood of making a follow-up SEO with the dummy variable $S E O$, which is equal to 1 if the firm issues seasoned equity meeting the conditions specified above within three years after the IPO date (and zero otherwise). We measure the size of the seasoned equity offering (SEO/IPO) as the SEO value expressed as a percentage of the IPO value. In line with Jegadeesh, Weinstein and Welch (1993) and Francis et al. (2010), we set the variable equal to 0 if a firm does not issue seasoned equity within three years after the IPO. We measure the SEO timing (LnDays) as the natural logarithm of the number of calendar days between the IPO and SEO. In line with Francis et al. (2010), we set the dependent variable equal to the natural logarithm of the maximum value, i.e. 1,095 days, if a firm does not issue seasoned equity within three years following the IPO. We measure the stock market reaction to the SEO announcement (AnnRea) as the abnormal three-day return over -1 day to +1 day surrounding the SEO announcement. To estimate abnormal returns, we use the standard market model with the Warsaw Stock Exchange index (WIG) as a proxy for the market return. The market model is estimated on daily returns from the period between -266 days to -11 days prior to the SEO announcement and we require the stock returns to be available for at least 100 days for estimation (this condition does not eliminate any observations).

The definition of IPO underpricing $(U P)$ is complicated somewhat by the use of allotment certificates (PDAs_- "prawo do akcji", i.e. "right to share") on the WSE. 
PDAs are financial instruments that allow investors to trade the rights prior to the actual stock quotation. Of the total number of 153 IPOs in our sample, 134 companies issued allotment certificates that were traded before the stocks were listed. Trading in PDAs is subject to the same regulation as equity trading, the prices are quoted in the same trading system and the price of a PDA is mostly identical to the stock price. Nevertheless, allotment certificates do not give full shareholder rights before they are converted to regular stocks (Szyszka and Zielonka, 2007). Due to the similar regulatory framework for stocks and PDAs, we expect the intrinsic value to already be revealed at the end of the first trading day regardless of whether it is the PDAs or actual stocks that are traded. We define UP as the percentage change between the IPO issue price and the first-day closing market price of either the allotment certificates (PDAs) or stocks, whichever exists first. This treatment allows the same time for price revelation of stocks with and without PDAs. Nevertheless, to control for possible differences between firms that use PDAs and those that do not, we include the dummy variable $P D A$, which is equal to 1 if the PDAs are used in all our regressions. As a robustness check we define IPO underpricing based on the issue price and the closing price of the stock on the first trading day. Our results and their significance are not affected by this modification of the methodology.

We measure the abnormal aftermarket returns AbRet1 (AbRet2) over the period between one and 20 ( 21 to 40 ) trading days after the initiation of trading in the IPO stock. The minimum time lag between the IPO and SEO in our sample is 178 calendar days, so the abnormal aftermarket returns are not affected by a concurrent SEO. Consistent with prior research (Jegadeesh, Weinstein and Welch, 1993; Francis et al., 2010), the abnormal aftermarket returns are defined as the raw return minus the beta times the market return. Betas are estimated using the market model based on daily stock returns in the estimation window between 41 and 140 trading days following the issue of IPO stocks. Note that the market model cannot be estimated using the pre-IPO data because no stock price exists before the actual IPO. We use the Warsaw Stock Exchange index (WIG) as a proxy for the market return.

We include several control variables. LnIPO captures the IPO size and it is defined as a natural logarithm of the IPO value, i.e. the number of shares sold times the issue price. $P D A$ is a dummy variable equal to 1 if a firm issues allotment certificates ("prawo do akcji") and zero otherwise. To control for firm size, we include LnAssets defined as the natural logarithm of the company's assets at the end of the fiscal year preceding the IPO. As a robustness check, we replace LnAssets with LnSales, which captures the natural logarithm of the firm's net sales at the end of the fiscal year preceding the IPO. This methodological modification does not qualitatively affect our results. To control for governance quality in our sample years, we compute an Index of Governance Indicators (GI Index). We use country-year level data provided by the World Bank and compiled by Kaufmann et al. (2009) on voice and accountability, government effectiveness, regulatory quality and rule of law. We first normalize the individual measures (by subtracting their mean and dividing the result by standard deviation) and then we compute the mean value of the four normalized measures. Our limited sample size does not allow us to control for individual industries. We thus form industry groups based on the Global Industry Classification Standard (GICS) and we distinguish between financial firms (Ind_Financials), high-tech firms (Ind_Hi-tech) and low-tech firms (Ind_Low-tech). 
Table 4 Descriptive Statistics

\begin{tabular}{|c|c|c|c|c|c|c|}
\hline & $\mathbf{N}$ & Mean & StdDev & Median & Min & Max \\
\hline \multicolumn{7}{|c|}{ Panel A: All IPOs } \\
\hline UP & 153 & 0.140 & 0.292 & 0.061 & -0.283 & 1.599 \\
\hline$A b R e t 1$ & 153 & -0.005 & 0.155 & -0.022 & -0.291 & 0.553 \\
\hline AbRet2 & 153 & 0.014 & 0.142 & -0.007 & -0.356 & 0.508 \\
\hline LnIPO & 153 & 17.361 & 1.311 & 17.297 & 13.503 & 20.547 \\
\hline$P D A$ & 153 & 0.856 & 0.352 & 1.000 & 0.000 & 1.000 \\
\hline SEO & 153 & 0.222 & 0.417 & 0.000 & 0.000 & 1.000 \\
\hline SEO/IPO & 153 & 0.336 & 0.993 & 0.000 & 0.000 & 5.889 \\
\hline LnAssets & 153 & 10.722 & 1.460 & 10.823 & 6.795 & 13.536 \\
\hline GI Index & 153 & 0.013 & 0.956 & -0.482 & -0.966 & 2.492 \\
\hline \multicolumn{7}{|c|}{ Panel B: IPOs with an SEO } \\
\hline UP & 34 & 0.245 & 0.428 & 0.103 & -0.167 & 1.599 \\
\hline$A b \operatorname{Ret} 1$ & 34 & -0.017 & 0.167 & -0.028 & -0.291 & 0.484 \\
\hline AbRet2 & 34 & 0.025 & 0.154 & 0.000 & -0.356 & 0.481 \\
\hline LnIPO & 34 & 16.963 & 1.402 & 16.876 & 13.503 & 19.855 \\
\hline$P D A$ & 34 & 0.882 & 0.327 & 1.000 & 0.000 & 1.000 \\
\hline SEO & 34 & 1.000 & 0.000 & 1.000 & 1.000 & 1.000 \\
\hline SEO/IPO & 34 & 1.513 & 1.645 & 0.704 & 0.001 & 5.889 \\
\hline LnDays & 34 & 6.178 & 0.557 & 6.311 & 5.182 & 6.987 \\
\hline AnnRea & 34 & 0.003 & 0.057 & -0.006 & -0.077 & 0.158 \\
\hline LnSEO & 34 & 16.762 & 2.140 & 17.034 & 9.010 & 19.085 \\
\hline LnAssets & 34 & 10.495 & 1.616 & 10.612 & 6.795 & 13.507 \\
\hline GI Index & 34 & 0.262 & 1.084 & 0.604 & -0.966 & 2.492 \\
\hline \multicolumn{7}{|c|}{ Panel C: IPOs without an SEO } \\
\hline UP & 119 & 0.110 & 0.233 & 0.054 & -0.283 & 1.256 \\
\hline$A b R e t 1$ & 119 & -0.002 & 0.152 & -0.022 & -0.291 & 0.553 \\
\hline AbRet2 & 119 & 0.011 & 0.140 & -0.009 & -0.356 & 0.508 \\
\hline LnIPO & 119 & 17.474 & 1.267 & 17.394 & 13.503 & 20.547 \\
\hline$P D A$ & 119 & 0.849 & 0.360 & 1.000 & 0.000 & 1.000 \\
\hline LnAssets & 119 & 10.787 & 1.413 & 10.910 & 6.883 & 13.536 \\
\hline GI Index & 119 & -0.059 & 0.908 & -0.482 & -0.966 & 2.492 \\
\hline
\end{tabular}

Notes: The table reports the number of observations $(N)$, mean (Mean), standard deviation (StdDev), median (Median), minimum (Min) and maximum (Max) for the primary variables for the full sample of all IPOs (Panel A), for the IPOs that were followed by an SEO within the three subsequent years (Panel B), and for the IPOs that were not followed by an SEO within the three subsequent years (Panel C). UP is IPO underpricing defined as the percentage difference between the closing price on the first trading day and the issuing price. AbRet1 (AbRet2) are the abnormal aftermarket returns measured over the period between one and 20 (21 to 40 ) trading days after the IPO date. LnIPO is the IPO size defined as a natural logarithm of IPO value (the number of shares sold times the issue price). PDA is a dummy variable that is equal to 1 if a firm issues allotment certificates ("prawo do akcji") and zero otherwise. $S E O$ is the dummy variable equal to 1 if a firm issues seasoned equity in the three years following the IPO and zero otherwise. SEO/IPO is the relative SEO size defined as a ratio of the SEO value to the IPO value; the variable is set to 0 if no SEO exists. LnAssets is the natural logarithm of a company's total assets prior to the IPO. GI Index is a standardized index calculated as the mean value of four standardized components of governance indicators (voice and accountability, government 
effectiveness, regulatory quality and rule of law) published by the World Bank. LnDays is the natural logarithm of the number of calendar days between the IPO and the SEO; the variable is set to $\ln (1095)$ if no SEO was made in the three years following the IPO. AnnRea is the stock market's reaction to the SEO announcement measured as the abnormal three-day return over -1 day to +1 day surrounding the SEO announcement. LnSEO is the natural logarithm of the SEO value. All variables are Winsorized at $1 \%$.

Detailed information about the assignment of individual industries to the industry groups is provided in Table 5. We include year fixed effects that control for the variation driven by economic conditions and other effects concentrated over time. To mitigate the effect of outliers, we Winsorize all variables at the $1 \%$ level. As a robustness check, we also compute results based on the non-Winsorized sample. This does not materially affect our results.

Table 4 shows the descriptive statistics for our final sample. Panel A is based on the entire sample, Panel B on the subsample of firms with a follow-up SEO, and Panel $\mathrm{C}$ on the subsample of firms that do not make an SEO within three years after the IPO. The mean (median) value of IPO underpricing for the full sample is $14.0 \%$ $(6.1 \%)$. More than one in five firms $(22.2 \%)$ issue an SEO within three years after the IPO. The IPOs that are followed by an SEO are more underpriced both when it comes to the mean $(24.5 \%$ relative to $11.0 \%)$ and median underpricing $(10.3 \%$ relative to $5.4 \%)$. The average IPO size (LnIPO) is smaller for firms that issued a followup SEO (16.963 vs. 17.474). The average size of firms (LnAssets) that issued a followup SEO is smaller (10.495 vs. 10.787). This provides some preliminary evidence that is consistent with the signaling hypothesis.

The mean abnormal return over the first 20 trading days following the IPOs (AbRet 1) is -0.002 for firms that did not make an SEO and -0.017 for firms with an SEO. The mean abnormal return over the second 20 trading days after the IPOs (AbRet2) is positive for both groups. Median values of abnormal aftermarket returns (AbRet1, AbRet2) are slightly negative for all groups. At this point we thus do not observe any systematic differences in AbRet1 and AbRet 2 for firms with and without an SEO.

Table 5 shows statistics for individual years and industry groups. The average proceeds-weighted IPO underpricing is positive in all years, but there is a considerable variation over time ranging from $4.31 \%$ in 2005 to $17.81 \%$ in 2006 for the Winsorized sample. The aggregate proceeds are 12.64 billion Polish zloty (PLN) and the total amount of money left on the table by the issuers is PLN 1.53 billion. The average IPO underpricing is larger for high-tech than for low-tech industries $(18.30 \%$ vs. $11.84 \%)$.

Table 6 shows the correlation matrix for the variables we use. This table provides evidence about the expected correlation between IPO underpricing (UP) with probability of SEO issue $(S E O)$, the relative size of the SEO as a fraction of the IPO (SEO/IPO), the time between the IPO and the SEO (LnDays), the size of the firm a year prior to the IPO (LnAssets) and the index of governance indicators (GI Index). Except for the relative size of the SEO as a fraction of the IPO (SEO/IPO), all these correlations are significant at the 5\% level. On the other hand, none of the correlations between the abnormal market returns (AbRet1 and AbRet2) and the SEO characteristics is significant. If anything, the correlations with SEO and $S E O / I P O$ are negative (insignificant), contrary to the market feedback hypothesis. 
Table 5 IPO Underpricing by Year and Industry

\begin{tabular}{|c|c|c|c|c|c|}
\hline \multirow{2}{*}{$\begin{array}{l}\text { Yearl } \\
\text { Industry Group }\end{array}$} & \multirow[b]{2}{*}{$\mathbf{N}$} & \multicolumn{2}{|c|}{ UP } & \multirow{2}{*}{$\begin{array}{l}\text { UP value } \\
\text { (bln) }\end{array}$} & \multirow{2}{*}{$\begin{array}{l}\text { IPO value } \\
\text { (bln) }\end{array}$} \\
\hline & & $\begin{array}{c}\text { Equal- } \\
\text {-weighted (\%) }\end{array}$ & $\begin{array}{c}\text { Proceeds- } \\
\text {-weighted(\%) }\end{array}$ & & \\
\hline \multicolumn{6}{|c|}{ Panel A: Winsorized Data at 1\% Level-Year } \\
\hline 2005 & 27 & 8.31 & 4.31 & 0.08 & 1.77 \\
\hline 2006 & 33 & 26.48 & 17.81 & 0.56 & 3.11 \\
\hline 2007 & 61 & 14.97 & 12.73 & 0.90 & 5.76 \\
\hline 2008 & 22 & 0.65 & 6.38 & 0.10 & 1.50 \\
\hline 2009 & 10 & 11.58 & 13.55 & 0.07 & 0.49 \\
\hline Total & 153 & 13.99 & 12.10 & 1.70 & 12.64 \\
\hline \multicolumn{6}{|c|}{ Panel B: Winsorized Data at 1\% Level_-Industry } \\
\hline Energy & 1 & 159.91 & 159.91 & 0.19 & 0.12 \\
\hline Materials & 6 & -0.60 & 0.07 & 0.00 & 0.39 \\
\hline Industrial & 37 & 18.00 & 17.26 & 0.49 & 2.85 \\
\hline Consumer Discretionary & 33 & 7.55 & 9.57 & 0.40 & 4.13 \\
\hline Consumer Staples & 19 & 5.08 & 4.15 & 0.06 & 1.55 \\
\hline Utilities & 3 & 0.25 & -0.06 & 0.00 & 0.08 \\
\hline Low-Tech & 99 & 11.84 & 12.54 & 1.14 & 9.12 \\
\hline Financials & 13 & 16.85 & 3.10 & 0.06 & 1.91 \\
\hline Financials & 13 & 16.85 & 3.10 & 0.06 & 1.91 \\
\hline Health Care & 5 & 41.33 & 81.31 & 0.14 & 0.17 \\
\hline Information Technology & 33 & 14.46 & 12.66 & 0.18 & 1.42 \\
\hline Telecommunication & 3 & 22.11 & 27.50 & 0.01 & 0.03 \\
\hline Hi-Tech & 41 & 18.30 & 20.00 & 0.32 & 1.62 \\
\hline
\end{tabular}

Notes: Equal-weighted and proceeds-weighted IPO underpricing (UP). Proceeds-weighted is weighted by the IPO value. UP value represents the aggregate amount of money left on the table computed as UP times IPO value. IPO value represents the aggregate proceeds, i.e. the value of the IPO issued in an individual year. Panel $A$ is based on data Winsorized at the $1 \%$ level for individual years and Panel $B$ is based on data Winsorized at the $1 \%$ level for individual industries (GICS sectors).

The correlation matrix thus suggests associations consistent with the signaling hypothesis, but not with the market feedback hypothesis.

We formally test Hypotheses 1 and 1A on SEO probability using the logit model below. If the decision to make an SEO follows a signal sent by the issuer in the IPO (Hypothesis 1), we expect the coefficient $\beta_{1}$ at UP to be positive. Alternatively, if the likelihood of the SEO is driven by how well the IPO is received by the market (Hypothesis 1A), we expect the coefficients $\beta_{2}$ and $\beta_{3}$ at AbRet1 and AbRet2 to be positive.

$$
\operatorname{Prob}(S E O)_{i}=\frac{e^{\alpha+\beta_{1}{ }^{*} U P+\beta_{2}{ }^{*} \operatorname{Abret} 1+\beta_{3}{ }^{*} \operatorname{Abret} 2+\delta^{*} C T R L S+\gamma^{*} Y F E+u_{i}}}{1+e^{\alpha+\beta_{1}{ }^{*} U P+\beta_{2}{ }^{*} \operatorname{Abret} 1+\beta_{3}{ }^{*} \operatorname{Abret} 2+\delta^{*} C T R L S+\gamma^{*} Y F E+u_{i}}}
$$

We use the following Tobit regression to test Hypotheses 2 and 2A on the determinants of the relative SEO size. We use the Tobit regression because SEO size is 
Table 6 Correlation Matrix

\begin{tabular}{|c|c|c|c|c|c|c|c|c|c|c|}
\hline & UP & AbRet1 & AbRet2 & LnIPO & $P D A$ & SEO & SEO/IPO & LnDays & LnAssets & GI Index \\
\hline UP & 1 & & & & & & & & & \\
\hline$A b R e t 1$ & $\begin{array}{l}0.187 \\
(0.02)\end{array}$ & 1 & & & & & & & & \\
\hline$A b R e t 2$ & $\begin{array}{l}-0.081 \\
(0.32)\end{array}$ & $\begin{array}{l}-0.014 \\
(0.86)\end{array}$ & 1 & & & & & & & \\
\hline LnIPO & $\begin{array}{l}-0.038 \\
(0.64)\end{array}$ & $\begin{array}{c}0.084 \\
(0.30)\end{array}$ & $\begin{array}{l}-0.062 \\
(0.45)\end{array}$ & 1 & & & & & & \\
\hline$P D A$ & $\begin{array}{l}0.097 \\
(0.23)\end{array}$ & $\begin{array}{l}-0.040 \\
(0.62)\end{array}$ & $\begin{array}{l}0.019 \\
(0.82)\end{array}$ & $\begin{array}{l}-0.193 \\
(0.02)\end{array}$ & 1 & & & & & \\
\hline SEO & $\begin{array}{l}0.194 \\
(0.02)\end{array}$ & $\begin{array}{l}-0.041 \\
(0.62)\end{array}$ & $\begin{array}{l}0.041 \\
(0.61)\end{array}$ & $\begin{array}{l}-0.163 \\
(0.04)\end{array}$ & $\begin{array}{l}0.040 \\
(0.63)\end{array}$ & 1 & & & & \\
\hline SEO/IPO & $\begin{array}{l}0.121 \\
(0.14)\end{array}$ & $\begin{array}{l}-0.091 \\
(0.26)\end{array}$ & $\begin{array}{l}-0.046 \\
(0.58)\end{array}$ & $\begin{array}{l}-0.298 \\
(0.00)\end{array}$ & $\begin{array}{l}-0.009 \\
(0.92)\end{array}$ & $\begin{array}{l}0.636 \\
(0.00)\end{array}$ & 1 & & & \\
\hline LnDays & $\begin{array}{l}-0.185 \\
(0.02)\end{array}$ & $\begin{array}{l}-0.023 \\
(0.78)\end{array}$ & $\begin{array}{l}-0.042 \\
(0.61)\end{array}$ & $\begin{array}{l}0.000 \\
(1.00)\end{array}$ & $\begin{array}{l}-0.040 \\
(0.63)\end{array}$ & $\begin{array}{l}-0.797 \\
(0.00)\end{array}$ & $\begin{array}{l}-0.389 \\
(0.00)\end{array}$ & 1 & & \\
\hline LnAssets & $\begin{array}{l}-0.178 \\
(0.03)\end{array}$ & $\begin{array}{l}-0.024 \\
(0.76)\end{array}$ & $\begin{array}{l}-0.045 \\
(0.58)\end{array}$ & $\begin{array}{l}0.685 \\
(0.00)\end{array}$ & $\begin{array}{l}-0.265 \\
(0.00)\end{array}$ & $\begin{array}{l}-0.083 \\
(0.31)\end{array}$ & $\begin{array}{l}-0.118 \\
(0.15)\end{array}$ & $\begin{array}{l}-0.020 \\
(0.80)\end{array}$ & 1 & \\
\hline Index GI & $\begin{array}{l}-0.206 \\
(0.01)\end{array}$ & $\begin{array}{l}-0.125 \\
(0.13)\end{array}$ & $\begin{array}{l}-0.010 \\
(0.90)\end{array}$ & $\begin{array}{l}-0.288 \\
(0.00)\end{array}$ & $\begin{array}{l}-0.173 \\
(0.03)\end{array}$ & $\begin{array}{l}0.140 \\
(0.08)\end{array}$ & $\begin{array}{l}0.212 \\
(0.01)\end{array}$ & $\begin{array}{l}-0.047 \\
(0.56)\end{array}$ & $\begin{array}{l}0.098 \\
(0.23)\end{array}$ & 1 \\
\hline
\end{tabular}

Notes: Pairwise correlation coefficients and the corresponding $p$-values (in parentheses). Correlations significant at better than the $5 \%$ level are highlighted in bold. UP is IPO underpricing defined as the difference between the closing price first trading day and the issuing price. AbRet1 (AbRet2) are the abnormal aftermarket returns measured over the period between 1 and 20 ( 21 to 40 ) trading days after the IPO date. LnIPO is the IPO size defined as a natural logarithm of IPO value (the number of shares sold times the issue price). PDA is a dummy variable that is equal to 1 if a firm issues allotment certificates ("prawo do akcji") and zero otherwise. SEO is the dummy variable equal to 1 if a firm issues seasoned equity in the three years following the IPO and zero otherwise. SEO/IPO is the relative SEO size defined as a ratio of the SEO value to the IPO value; the variable is set to 0 if no SEO exists. LnDays is the natural logarithm of the number of calendar days between the IPO and SEO; the variable is set to $\ln (1095)$ if no SEO exists. LnAssets is the natural logarithm of company's total assets prior to IPO. GI Index is a standardized index calculated as the mean value of four standardized components of governance indicators (voice and accountability, government effectiveness, regulatory quality and rule of law) published by the World Bank. All variables are Winsorized at the $1 \%$ level.

bound below by zero (the dependent variable is left-censored). If firms use IPO underpricing as a signaling device (Hypothesis 2), we expect the $\beta_{1}$ coefficient at $U P$ to be positive because firms that underprice IPOs more are expected to raise a larger fraction of new equity at the SEO to benefit from the more favorable terms they can obtain after credibly revealing their quality. On the other hand, if SEO size is determined after the issuer observes the aftermarket returns, as suggested in Hypothesis 2A, we expect the $\beta_{2}$ and $\beta_{3}$ coefficients of AbRet 1 and Abret 2 to be positive. 


$$
\left(\frac{S E O}{I P O}\right)_{i}=\left\{\begin{array}{ll}
\alpha+\beta_{1} * U P+\beta_{2} * \text { Abret } 1+\beta_{3} * \text { Abret } 2+\delta * C T R L S+ \\
+\gamma * Y F E+u_{i} & \text { if } R H S>0 \\
0 & \text { otherwise }
\end{array}\right\}
$$

We use a Tobit regression to test Hypotheses 3 and $3 \mathrm{~A}$ on the timing of the SEO. The Tobit specification accounts for the fact that the dependent variable is rightcensored at a logarithm of 1,095 days. If firms use IPO underpricing as a signaling device, Hypothesis 3 suggests that the $\beta_{1}$ coefficient at $U P$ should be negative because firms that underprice their IPOs to signal their type are likely to return to the stock market sooner and benefit from the more favorable terms they can obtain after credibly revealing their quality. Alternatively, if SEO timing is determined only after the issuer observes the aftermarket returns as suggested in Hypothesis $3 \mathrm{~A}$, we expect the $\beta_{2}$ and $\beta_{3}$ coefficients of variables AbRet 1 and Abret 2 to be negative.

$$
\text { LnDays }_{i}=\left\{\begin{array}{ll}
\alpha+\beta_{1} * U P+\beta_{2} * \text { Abret } 1+\beta_{3} * \text { Abret } 2+\delta * C T R L S+ \\
+\gamma * Y F E+u_{i} & \text { if } \operatorname{LHS}<\operatorname{Ln}(1095) \\
\operatorname{Ln}(1905) & \text { otherwise }
\end{array}\right\}
$$

We use an ordinary least square regression (OLS) to test Hypotheses 4 and 4A on the determinants of the stock market's reaction to the announcement of the SEO issue. If a firm uses IPO underpricing as a signaling device, we expect a weaker (less negative) price reaction to the SEO announcement. Thus, Hypothesis 4 predicts the $\beta_{1}$ coefficient at $U P$ to be positive, reflecting the less negative stock market reaction. On the other hand, if the decision to make an SEO is determined based on the observed aftermarket returns as suggested in Hypothesis 4A, we expect the $\beta_{2}$ and $\beta_{3}$ coefficients of variables AbRet 1 and Abret 2 to be positive:

$$
\begin{aligned}
\text { AnnRea }= & \alpha+\beta_{1} * U P+\beta_{2} * \text { Abret } 1+\beta_{3} * \text { Abret } 2+\beta_{4} * \text { LnDays }+ \\
& +\beta_{5} * \text { LnSEO }+\beta_{6} * \frac{S E O}{I P O}+\delta * C T R L S+\gamma * Y F E+u_{i}
\end{aligned}
$$

\section{Empirical Results}

\subsection{Signaling Model}

Our results, presented in Table 7, are consistent with the prediction of the signaling model. In line with Hypothesis 1, the results of the logit regression show a positive and statistically significant relationship (z-stat 2.51 ) between the level of underpricing $(U P)$ and the probability of an SEO $(\operatorname{Prob}(S E O))$, which implies that firms with more underpriced IPOs are more likely to make an SEO. We also find support for Hypothesis 2, which expects firms with more underpriced IPOs to issue a larger portion of new equity at the subsequent SEOs. The slope coefficient of IPO underpricing $(U P)$ is positive and statistically significant ( $t$-stat 2.37). Furthermore, our results are consistent with Hypothesis 3, which suggests that firms with more underpriced IPOs make their SEOs sooner. In a regression where the dependent 
Table 7 Signaling by IPO Underpricing

\begin{tabular}{|c|c|c|c|c|}
\hline & Model 1 & Model 2 & Model 3 & Model 4 \\
\hline & SEO & SEO/IPO & LnDays & AnnRea \\
\hline \multirow[t]{2}{*}{ Constant } & 3.125 & $7.602^{*}$ & $6.736^{* * *}$ & -0.17 \\
\hline & $(0.94)$ & $(1.77)$ & (3.03) & $(-0.35)$ \\
\hline \multirow[t]{2}{*}{ UP } & $1.798^{* *}$ & $2.132^{* *}$ & $-1.119^{* *}$ & 0.02 \\
\hline & $(2.51)$ & $(2.37)$ & $(-2.40)$ & $(0.20)$ \\
\hline \multirow[t]{2}{*}{$A b R e t 1$} & -0.929 & -0.981 & 0.202 & -0.04 \\
\hline & $(-0.67)$ & $(-0.56)$ & $(0.22)$ & $(0.27)$ \\
\hline \multirow[t]{2}{*}{ AbRet2 } & 0.562 & -0.369 & -0.296 & 0.00 \\
\hline & $(0.37)$ & $(-0.19)$ & $(-0.29)$ & $(0.02)$ \\
\hline \multirow[t]{2}{*}{ LnIPO } & -0.319 & $-0.689^{*}$ & 0.099 & 0.00 \\
\hline & $(-1.19)$ & $(-1.95)$ & $(0.55)$ & $(0.10)$ \\
\hline \multirow[t]{2}{*}{$P D A$} & 0.595 & 0.725 & -0.475 & 0.04 \\
\hline & $(0.89)$ & $(0.82)$ & $(-1.04)$ & $(0.54)$ \\
\hline \multirow[t]{2}{*}{ LnAssets } & 0.107 & 0.201 & -0.051 & \\
\hline & $(0.48)$ & $(0.68)$ & $(-0.34)$ & \\
\hline \multirow[t]{2}{*}{ Ind_Financials } & -0.952 & -0.517 & 0.826 & \\
\hline & $(-1.02)$ & $(-0.46)$ & $(1.28)$ & \\
\hline \multirow[t]{2}{*}{ Ind_Hi-tech } & -0.121 & -0.190 & -0.026 & \\
\hline & $(-0.25)$ & $(-0.30)$ & $(-0.08)$ & \\
\hline \multirow[t]{2}{*}{ LnDays } & - & - & - & -0.00 \\
\hline & & & & $(-0.11)$ \\
\hline \multirow[t]{2}{*}{ LnSEO } & - & - & - & 0.01 \\
\hline & & & & $(0.92)$ \\
\hline \multirow[t]{2}{*}{ SEO/IPO } & - & - & - & 0.00 \\
\hline & & & & $(0.18)$ \\
\hline Year fixed effect & Yes & Yes & Yes & Yes \\
\hline $\mathrm{N}$ & 153 & 153 & 153 & 34 \\
\hline Pseudo $R^{2}$ & 0.12 & 0.09 & 0.07 & - \\
\hline
\end{tabular}

Notes: Model 1-logit regression estimates of the relationship between stock returns at the time of the IPO and the probability of a seasoned equity offering (SEO). Model 2-Tobit regression analysis of the relationship between stock returns at the time of the IPO and the size of the SEO as a fraction of the IPO (SEO/IPO). Model 3-Tobit regression analysis of the relationship between stock returns at the time of the IPO and the time between the IPO and SEO (LnDays). Model 4-OLS regression with the dependent variable is the abnormal SEO three-day announcement price reaction (AnnRea). The independent variables are UP (IPO underpricing, first-day return, measured as (P1-P0)/P0), $A b R e t 1$ and $A b R e t 2$ are the abnormal aftermarket returns in the two 20-day periods after the IPO. $L n I P O$ is the natural logarithm of the IPO size; PDA is a dummy variable and equal to 1 when shares are traded as rights to shares after the IPO date, and 0 otherwise. LnDays is the natural logarithm of the time between the SEO and IPO. LnSEO is the natural logarithm of the SEO issue size. SEO/IPO is a proportion of the SEO issue size to IPO size. LnAssets is the natural logarithm of the company's total assets prior to the IPO. Ind_Finacials is a dummy equal to 1 if the firm is from 40-Financials (GICS sector) and zero otherwise. Ind Hi-tech is a dummy equal to 1 if the firm is from one of the following GICS sectors: 35-Health care, 45-Information technology or 50-Telecommunications. All data are Winsorized at the $1 \%$ level to control for the effect of outliers. Z-stats (Model 1 ) and $t$-stats (Model $2,3,4$ ) are reported in parentheses and the symbols ${ }^{*},{ }^{* *},{ }^{* * *}$ denote statistical significance at the $10 \%, 5 \%$ and $1 \%$ levels, respectively. 
variable is the log of the number of days between the IPO and the SEO (LnDays), the slope coefficient of the IPO underpricing $(U P)$ is negative and statistically significant $(t$-stat -2.40$)$. Note that despite the relatively low number of observations (153 IPOs and 34 SEOs), all these results are statistically significant at the $5 \%$ level ( $p$-values $0.012,0.019$ and 0.018 respectively) ( $p$-values not tabulated).

Conversely, we do not find support for Hypothesis 4, which proposes that the market reacts less unfavorably to announcements of SEOs by firms with more underpriced IPOs. The effect of IPO underpricing $(U P)$ on announcement reaction is not statistically different from zero $(t$-stat 0.20$)$. We believe that this insignificant result can be caused by different implications of the SEO announcement in an emerging market relative to the established market. As argued above, the existing evidence suggests that on established markets investors typically view an SEO announcement as bad news either because it suggests that the given company's managers had to resort to the least preferred source of financing (pecking order) or because it reveals the managers' belief that the stock may be overvalued (market timing). However, the degree to which the investors perceive an SEO announcement as a negative signal may depend on the economic circumstances. Choe, Masulis and Nanda (1993) show that the price reaction to an SEO announcement is less negative in times of economic expansion (rather than contraction) when the adverse selection problem is less severe because firms have more promising investment opportunities and there is less uncertainty about the value of their assets.

In an emerging market populated mostly by growing companies, SEOs may be motivated simply by additional capital needs rather than by managerial preferences for certain capital sources or their considerations about the appropriateness of the current stock price. To assess the plausibility of this idea, we compute the mean stock market reaction to the SEO announcement. We find that the mean three-day stock market reaction to the SEO announcement is $+0.3 \%$ (not tabulated), which is not statistically different from zero ( $t$-stat 0.29$)$. This implies that in an emerging market investors do not view an SEO announcement as bad news and therefore there is little reason to expect the stock market's reaction to be affected by IPO underpricing. This result is consistent with Gajewski and Ginglinger (2002), who report that, in contrast to the U.S. results, several studies on European and Australian data find a non-negative or even positive stock price reaction to SEO announcements.

Throughout this paper we argue that the results in support of the signaling hypothesis that we document in Poland are likely to be driven by the weaker institutional environment, which makes the use of a signaling strategy more attractive for issuers. As our sample covers only one country, we cannot benefit from crosssectional variation in the quality of the institutional setting to conclusively demonstrate its effect on the use of signaling. Nevertheless, to provide some suggestive evidence on the question, we exploit the time-series variation of the quality of the institutional environment. We include in our regressions the GI Index that captures the quality of the institutional environment. The first three models of Table 8 show that there is a slightly positive (insignificant) association between the GI Index and subsequent SEO activity, which implies that the better the institutional framework, the more likely the firms are to return to the market with an SEO, to issue a larger SEO and to make the SEO sooner after the IPO. More importantly, 
Table 8 Index of Governance Indicators

\begin{tabular}{|c|c|c|c|c|c|c|}
\hline & Model 1 & Model 2 & Model 3 & Model 4 & Model 5 & Model 6 \\
\hline & SEO & SEO/IPO & LnDays & SEO & SEO/IPO & LnDays \\
\hline \multirow[t]{2}{*}{ Constant } & 1.729 & 6.714 & $7.436^{* * *}$ & 1.517 & 6.579 & $7.509^{* * *}$ \\
\hline & $(0.55)$ & (1.54) & (3.37) & $(0.48)$ & (1.50) & (3.39) \\
\hline \multirow[t]{2}{*}{ UP } & $1.830^{* * *}$ & $2.154^{\star *}$ & $-1.186^{* * *}$ & $1.631^{* *}$ & $1.965^{*}$ & $-1.072^{* *}$ \\
\hline & (2.67) & (2.39) & $(-2.60)$ & (2.07) & (1.85) & $(-1.98)$ \\
\hline \multirow[t]{2}{*}{ AbRet1 } & -0.911 & -0.816 & 0.163 & -0.934 & -0.857 & 0.187 \\
\hline & $(-0.69)$ & $(-0.45)$ & $(0.18)$ & $(-0.70)$ & $(-0.47)$ & $(0.21)$ \\
\hline \multirow[t]{2}{*}{ AbRet2 } & 0.874 & 0.196 & -0.667 & 0.787 & 0.114 & -0.632 \\
\hline & $(0.62)$ & $(0.10)$ & $(-0.68)$ & $(0.56)$ & $(0.06)$ & $(-0.65)$ \\
\hline \multirow[t]{2}{*}{ LnIPO } & -0.235 & $-0.630^{*}$ & 0.075 & -0.234 & $-0.633^{*}$ & 0.078 \\
\hline & $(-0.96)$ & $(-1.81)$ & $(0.43)$ & $(-0.96)$ & $(-1.82)$ & $(0.45)$ \\
\hline \multirow[t]{2}{*}{$P D A$} & 0.219 & 0.126 & -0.228 & 0.277 & 0.179 & -0.258 \\
\hline & $(0.34)$ & $(0.15)$ & $(-0.53)$ & $(0.43)$ & $(0.21)$ & $(-0.59)$ \\
\hline \multirow[t]{2}{*}{ LnAssets } & 0.055 & 0.159 & -0.035 & 0.067 & 0.172 & -0.043 \\
\hline & $(0.26)$ & $(0.54)$ & $(-0.24)$ & $(0.31)$ & $(0.57)$ & $(-0.29)$ \\
\hline \multirow[t]{2}{*}{ Ind_Financials } & -0.824 & -0.381 & 0.700 & -0.890 & -0.440 & 0.741 \\
\hline & $(-0.91)$ & $(-0.34)$ & (1.12) & $(-0.95)$ & $(-0.39)$ & (1.16) \\
\hline \multirow[t]{2}{*}{ Ind_Hi-tech } & -0.010 & 0.030 & -0.105 & 0.024 & 0.063 & -0.123 \\
\hline & $(-0.02)$ & $(0.05)$ & $(-0.33)$ & $(0.05)$ & $(0.10)$ & $(-0.38)$ \\
\hline \multirow[t]{2}{*}{ GI Index } & 0.379 & 0.523 & -0.249 & 0.438 & 0.578 & -0.281 \\
\hline & $(1.54)$ & $(1.49)$ & $(-1.41)$ & (1.61) & (1.49) & $(-1.43)$ \\
\hline \multirow[t]{2}{*}{ GI Index * UP } & - & - & - & -0.465 & -0.425 & 0.248 \\
\hline & & & & $(-0.50)$ & $(-0.33)$ & $(0.38)$ \\
\hline Year fixed effect & Yes & Yes & Yes & Yes & Yes & Yes \\
\hline $\mathrm{N}$ & 153 & 153 & 153 & 153 & 153 & 153 \\
\hline Pseudo $R^{2}$ & 0.09 & 0.07 & 0.05 & 0.09 & 0.07 & 0.05 \\
\hline
\end{tabular}

Notes: Model 1-logit regression estimates of the relationship between stock returns at the time of the IPO and the probability of a seasoned equity offering (SEO). Model 2-Tobit regression analysis of the relationship between stock returns at the time of the IPO and the size of the SEO as a fraction of the IPO (SEO/IPO). Model 3-Tobit regression analysis of the relationship between stock returns at the time of the IPO and the time between the IPO and SEO (LnDays). Model 4-OLS regression with the dependent variable is the abnormal SEO three-day announcement price reaction (AnnRea). The independent variables are UP (IPO underpricing, first-day return, measured as (P1-P0)/P0), $A b R e t 1$ and $A b R e t 2$ are the abnormal aftermarket returns in the two 20-day periods after the IPO. LnIPO is the natural logarithm of the IPO size; PDA is a dummy variable and equal to 1 when shares are traded as rights to shares after the IPO date, and 0 otherwise. LnDays is the natural logarithm of the time between the SEO and IPO. LnSEO is the natural logarithm of the SEO issue size. SEO/IPO is a proportion of the SEO issue size to IPO size. LnAssets is the natural logarithm of the company's total assets prior to the IPO. GI Index is a standardized index calculated as the mean value of four standardized components of governance indicators (voice and accountability, government effectiveness, regulatory quality and rule of law) published by the World Bank. Ind_Finacials is a dummy equal to 1 if the firm is from 40-Financials (GICS sector) and zero otherwise. Ind Hi-tech is a dummy equal to 1 if the firm is from one of the following GICS sectors: 35 - Health care, 45 - Information technology or 50-Telecommunications. All data are Winsorized at the $1 \%$ level to control for the effect of outliers. Z-stats (Model 1) and $t$-stats (Model 2, 3, 4) are reported in parentheses and the symbols ${ }^{*},{ }^{* *},{ }^{* * *}$ denote statistical significance at the $10 \%, 5 \%$ and $1 \%$ levels, respectively. 


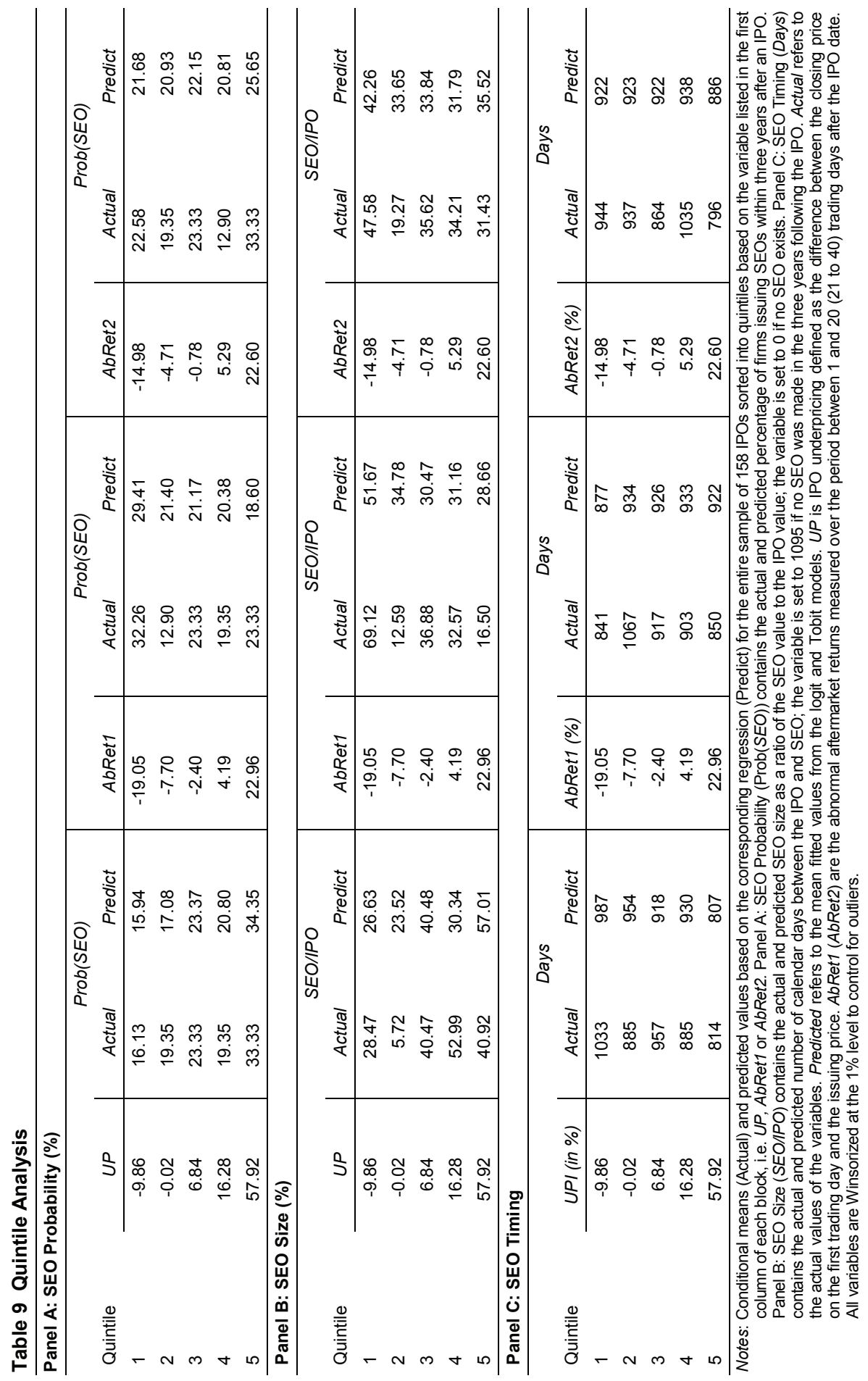

Finance a úvěr-Czech Journal of Economics and Finance, 65, 2015, no. 4 
the inclusion of the GI Index does not affect the importance of IPO underpricing and all the slope coefficients for $U P$ remain significant in the predicted direction.

The remaining three models of Table 8 include an interaction effect between the GI Index and UP. We suggest that the higher the GI Index and thus the better the institutional environment, the less likely the issuers should be to use signaling to overcome information asymmetry. Therefore we expect the interaction term to have the opposite sign to the main effect on $U P$, i.e. positive for the first two models on the likelihood and size of the SEO and negative for the third that measures the time lag between the IPO and SEO. All three interaction terms have the predicted sign, but none of these coefficients is significant. Given that our sample covers only five years, thus providing limited variation in the quality of the institutional environment, the significance of the GI Index is difficult to obtain. We therefore present these results merely as a robustness check. After inclusion of the interaction terms, all the slope coefficients at $U P$ are still significant, marginally so in Model $5(t$-stat $=1.85)$.

As a complement to the regression results, we provide a quintile analysis in Table 9 to evaluate the consistency of the reported results across the different sections of the distribution. Panel A presents the actual and predicted percentages of firms making SEOs within three years after their respective IPOs for each quintile based on IPO underpricing. Both the extreme quintiles 1 and 5 differ from the rest of the distribution. Only about $15.9 \%$ of the firms in the lowest UP quintile issue SEOs, compared to nearly $34.4 \%$ of the firms in the highest UP quintile. There is one exception (UP quintile 4) to the monotonic increase on SEO likelihood across the UP quintiles.

Panel B of Table 9 reports the actual and predicted mean of the relative SEO size $(S E O / I P O)$. There is a clear tendency of the relative SEO size to increase across the UP quintiles. The mean relative SEO size is $28.5 \%$ for the lowest quintile and $40.9 \%$ for the highest quintile. The interim quintiles 2 and 4 do not conform to the increasing pattern over the UP quintiles. The table also shows that the results on relative SEO size are primarily driven by the highest quintiles $3-5$, i.e. by firms with the highest level of underpricing. This is consistent with the prediction of the signaling theory: firms that are particularly aggressive in pricing their IPOs have the most to gain from distinguishing themselves from the rest of the population and eventually raise large amounts of equity through their subsequent SEOs.

Panel $\mathrm{C}$ of Table 9 shows the average number of days between the IPO and SEO for the individual UP quintiles. For the lowest IPO underpricing quintile, the mean number of days between IPO and SEO is 1,033 compared to 814 for the highest quintile, consistent with the tendency of firms that underprice their IPOs more to issue seasoned equity sooner. The pattern is fairly homogeneous across the individual quintiles, with the exception of quintile 2 , which shows the shortest lag ( 885 days). The decisions about SEO timing may have been affected by the financial crisis, which might have changed the expectations of issuers and made them postpone their SEOs.

\subsection{Market Feedback Model}

The results presented in the previous section provide fairly coherent evidence on the relevance of IPO underpricing for predicting SEO characteristics, which is 
consistent with the signaling model. Nevertheless, a common concern regarding these results is that they are also consistent with an alternative market feedback explanation.

To distinguish between the two competing explanations, we analyze the ability of the aftermarket returns to explain SEO characteristics. If market feedback is the dominant explanation, we expect the price discovery process to last for some time, and therefore not only the first-trading-day return $(U P)$ but also the return in the following days (AbRet1 and AbRet2) should be related to SEO characteristics. In contrast, if the issuers underprice IPOs to signal their quality, there is no reason to expect a relationship between the aftermarket returns (AbRet1 and AbRet2) and SEO characteristics. In fact, Jegadeesh, Weinstein and Welch (1993) report some evidence that SEO characteristics are related to IPO underpricing $(U P)$, but at the same time they find an even stronger association between SEO characteristics and aftermarket returns (AbRet1 and AbRet2). They conclude that this result fails to provide robust support for the signaling model because $U P$ may be just the first phase of the price discovery process and thus the former association may be driven by market feedback.

In contrast to Jegadeesh, Weinstein and Welch (1993) our results presented in Tables 7 and 9 provide unambiguous support for the signaling model. More specifically, we find no evidence of an association between aftermarket returns (AbRet1 and AbRet2) and subsequent SEO activity. The regression results reported in Table 7 show that neither AbRet1 nor AbRet2 is statistically significant in any of the four regression specifications. The $z$-statistics/t-statistics on AbRet 2 range from -0.29 to 0.37 , which clearly indicates the lack of association. The $z$-statistics $/ t$-statistics on AbRet 1 are larger in magnitude and they range from -0.67 to 0.22 , but the two largest $z$-statistics/t-statistics (in absolute value) in Model $1(-0.67)$ and Model $2(-0.56)$ are actually negative, which is contrary to the prediction of the market feedback hypothesis. In line with the regression results, the quintile analysis reported in Table 9 does not show any consistent pattern between AbRet1 and AbRet 2 and SEO characteristics. Hence, we find no evidence consistent with Hypotheses $1 \mathrm{~A}-4 \mathrm{~A}$ and so we may ascribe the result documented in the previous section to the signaling theory.

\subsection{Robustness Checks}

To assess the robustness of our results to the method choices, we perform several robustness checks. As neither of the robustness checks materially changes the interpretation of our findings, the additional results are not tabulated. Those results are available from the authors upon request.

To mitigate the effect of potential outliers, we Winsorize all the regression variables at the first and the ninety-ninth percentiles. We compute the regression based on the non-Winsorized data as a robustness check. In all regression specifications, the coefficient of $U P$ has the predicted sign as it retains (somewhat weaker) statistical significance at the $10 \%$ level. AbRet 1 and AbRet 2 remain insignificant in all regression specifications. Hence, our results are not driven by the elimination of some extreme observations that could have an offsetting effect to the dominant pattern documented for the Winsorized sample.

Due to the sample size the standard Winsorization at the $1 \%$ level affects only the most extreme observations. To verify that the results are not driven by unusual 
observations that are not affected by the standard outlier treatment, we Winsorize all variables at the $5 \%$ level. None of the results are materially affected and they maintain their significance at the $5 \%$ level.

It may be argued that foreign firms operate in a regulatory environment representing a mixture of requirements of the country of their incorporation and of the country of their listing. Hence, the lack of transparency may not be as severe for foreign firms provided that the higher quality of the institutions in the country of incorporation partly compensates for the weaker legal framework in the country of listing. As a robustness check, we exclude all foreign firms (seven additional observations after disregarding all dually listed firms) from our analysis. Our results are not materially affected and they maintain their significance at the 5\% level.

In our main test we consider PDAs equivalent to a regular stock and so we define $U P$ as the first-day return of the PDA or actual stock, whichever exists first. To address the concern that PDAs may not be sufficiently liquid and thus their firstday closing price may not reflect the intrinsic value of the underlying stock, we alternatively define IPO underpricing as the percentage difference between the firstday closing price of the actual stock less the issue price of the stock. Our results and their significance are not affected.

To concentrate on transactions aimed at raising additional capital, we require the SEO issue price to be above the nominal price. If we relax this condition, our inferences are not affected. The results are slightly less significant (retaining a 10\% significance level); the lower level of significance is consistent with our expectation that the transactions where the issue price is not above the nominal price are not motivated by realizing the signaling benefit and thus including them in the test introduces noise to the variable, thereby reducing the significance of the results.

Furthermore, in our main test we disregard observations for which the issue price is not available. As a robustness check, we include observations with a missing issue price for the tests of SEO probability (Hypothesis 1) and SEO timing (Hypothesis 3), for which information on the issue price is not essential. This methodology modification increases the number of valid SEOs from 34 to 54. The results are unchanged and they remain statistically significant at the conventional $5 \%$ level.

To assess the robustness of our results for firms from different industries and of different sizes, we perform our analysis separately for the three industry groupslow-tech, high-tech and financial-and for a sub-sample of large and small companies where we use the median company LnAssets as a cut-off. The results cannot be obtained for the financial industry group where the 13 observations are not sufficient to run our regressions. For the remaining two industries, we find that our result is driven by the low-tech industry group, which has a larger number of observations and where the presence of low-quality players may be larger, as may be the strong issuers' incentives to differentiate themselves (not tabulated). For the size groups, we find that within each sub-sample each of the three coefficients have the predicted sign, but none of them is significant; the $t$-statistics range from 0.86 to 1.52 (not tabulated). 


\section{Summary and Conclusion}

Following Francis et al. (2010), we test the signaling model by Welch (1989) in an emerging market where information asymmetry is likely to be high and where the information communicated through signaling may be valuable. Using a sample of 153 Polish IPOs from 2005 to 2009, we document significant underpricing of $14.0 \%$ on average. More importantly, we show that firms that underprice their IPOs more (i) are more likely to make an SEO in the three years after the IPO, (ii) make larger SEOs relative to the preceding IPO value and (iii) make their SEOs faster. Conversely, we find no association between the three SEO characteristics and the aftermarket return following the IPO. Our results are thus inconsistent with the alternative market feedback explanation and provide unambiguous support for the signaling theory.

Our findings suggest that the initial lack of empirical support may have been driven by the quality of the U.S. institutional setting, which reduces the a priori information asymmetry to an extent that renders signaling by IPO underpricing unattractive for issuers. In an emerging market setting in which large information asymmetries are likely, we find robust empirical support for the signaling model. The higher popularity of signaling in an emerging market is also likely to contribute to the documented negative association between IPO underpricing and the quality of the given country's legal system (Engelen and van Essen, 2010).

Future research may further explore the relationship between the propensity to use IPO underpricing for signaling purposes and the a priori information asymmetry on the market. First, it may be interesting to see if the companies that underprice their IPOs attract a different kind of investor. The level of information asymmetry may be different for domestic and foreign investors, as well as for private and institutional investors. It would be worth investigating whether IPO underpricing affects demand from these investor groups differently. Second, as emerging markets mature, market actors accumulate experience and build their reputations and institutional requirements converge to established standards, information asymmetry may decrease and alternative channels of communication may become more effective. Both of these developments may render signaling by means of IPO underpricing too costly relative to the alternatives. Future research may investigate if this prediction materializes. 


\section{REFERENCES}

Aussenegg W (2000): Privatization Versus Private Sector Initial Public Offerings in Poland. Multinational Finance Journal, 4:69-99.

Bommel J van, Vermaelen T (2003): Post-IPO capital expenditures and market feedback. Journal of Banking \& Finance, 27:275-305.

Boulton TJ, Smart SB, Zutter CJ (2010): IPO underpricing and international corporate governance. Journal of International Business Studies, 41:206-222.

Chang E, Chen C, Chi J, Young M (2008): IPO underpricing in China: New evidence from the primary and secondary markets. Emerging Markets Review, 9:1-16.

Choe H, Masulis RW, Nanda V (1993): Common stock offerings across the business cycle: Theory and evidence. Journal of Empirical Finance, 1:3-31.

Deb SS, Marisetty VB (2010): Information content of IPO grading. Journal of Banking \& Finance, 34:2294-2305.

Dobija D, Klimczak KM (2010): Development of accounting in Poland: Market efficiency and the value relevance of reported earnings. International Journal of Accounting, 45:356-374.

Engelen P-J, Essen M van (2010): Underpricing of IPOs: Firm-, issue- and country-specific characteristics. Journal of Banking \& Finance, 34:1958-1969.

Francis B, Hasan I, Li F (2001): Underpricing of Foreign and Domestic IPOs in the U.S. Market: Empirical Evidence. Financial Markets, Institutions and Instruments, 10:1-18.

Francis BB, Hasan I, Lothian JR, Sun X (2010): The signaling hypothesis revisited: Evidence from foreign IPOs. Journal of Financial and Quantitative Analysis, 45:81-106.

Gajewski JF, Ginglinger E (2002): Seasoned Equity Issues in a Closely Held Market: Evidence from France. European Finance Review, 6:291-319.

Gao X, Ritter JR (2010): The marketing of seasoned equity offerings. Journal of Financial Economics, 97:33-52.

Hasan I, Waisman M (2010): Going Public: An Empirical Investigation of U.S. Bound Israeli IPOs. Financial Markets, Instruments, and Institutions, 19:215-244.

Huang L, Shu Y (2014): Accounting Accruals, Future Operating Performance, and Public-Listing Age. Emerging Markets Finance and Trade, 50:164-82.

Jegadeesh N, Weinstein M, Welch I (1993): An empirical investigation of IPO returns and subsequent equity offerings. Journal of Financial Economics, 34:153-175.

Jelic R, Briston R (2003): Privatisation Initial Public Offerings: the Polish Experience. European Financial Management, 9:457-484.

Jewartowski T, Lizińska J (2012): Short- and Long-Term Performance of Polish IPOs. Emerging Markets Finance and Trade, 48:59-75.

Kaufmann D, Kraay A, Mastruzzi M (2009): Governance Matters VIII: Aggregate and Individual Governance Indicators, 1996-2008. World Bank Policy Research Working Paper, no. 4978.

Korczak P, Bohl MT (2005): Empirical evidence on cross-listed stocks of Central and Eastern European companies. Emerging Markets Review, 6:121-137.

Lischewski J, Voronkova S (2012): Size, value and liquidity. Do They Really Matter on an Emerging Stock Market? Emerging Markets Review, 13:8-25.

Ljungqvist A (2004): IPO Underpricing. In: Eckbo BE (Ed.): Handbook of Corporate Finance: Empirical Corporate Finance. Elsevier.

Loughran T, Ritter JR, Rydqvist K (1994): Initial public offerings: International insights. PacificBasin Finance Journal, 2:165-199.

Low S-W, Yong O (2011): Explaining over-subscription in fixed-price IPOs-Evidence from the Malaysian stock market. Emerging Markets Review, 12:205-216. 
Lyn E, Zychowicz E (2003): The performance of new equity offerings in Hungary and Poland. Global Finance Journal, 14:181-195.

Michaely R, Shaw WH (1994): The pricing of Initial Public Offerings: Test of Adverse Selection and Signaling theories. Review of Financial Studies, 7:279-319.

Mun M, Brooks R (2012): The roles of news and volatility in stock market correlations during the global financial crisis. Emerging Markets Review, 13:1-7.

Neupane S, Poshakwale SS (2012): Transparency in IPO mechanism: Retail investors' participation, IPO pricing and returns. Journal of Banking \& Finance, 36:2064-2076.

Patel SA, Balic A, Bwakira L (2002): Measuring transparency and disclosure at firm-level in emerging markets. Emerging Markets Review, 3:325-337.

Perotti EC (1995): Credible Privatization. American Economic Review, 85:847-859.

Shu P-G, Yeh Y-H, Su Y-H (2009): Decisions of Initial Public Offering Review Committees: Causes and Consequences. Emerging Markets Finance and Trade, 45:67-82.

Slovin MB, Sushka ME, Bendeck YM (1994): Seasoned common stock issuance following an IPO. Journal of Banking and Finance, 18:207-226.

Spiess KD, Pettway RH (1997): The IPO and First Seasoned Equity Sale: Issue Proceeds, Owner/ /Manager Wealth, and the Underpricing Signal. Journal of Banking and Finance, 21:967-988.

Szyszka A, Zielonka P (2007): The Disposition Effect Demonstrated on IPO Trading Available at SSRN: http://ssrn.com/abstract=964985 or http://dx.doi.org/10.2139/ssrn.964985

Welch I (1989): Seasoned offerings, imitation costs and the underpricing of initial public offerings. Journal of Finance, 44:421-450.

Wisniewski TP, Bohl MT (2005): The Information Content of Registered Insider Trading under Lax Law Enforcement. International Review of Law and Economics, 25:169-185. 